\title{
Perceived effects of transhumant practices on natural resource management in southern Mali
}

\author{
Clarisse Umutoni ${ }^{1}$ and Augustine Abioye Ayantunde ${ }^{2^{*}}$
}

\begin{abstract}
Recurring forage and water scarcity in the Sahelian zone of West Africa, especially in the dry season, has led to increased livestock movement into Sudano-Sahelian and Sudano-Guinean zones in the region. This increased movement by transhumant herders has resulted in growing competition over natural resources. Despite the strong presence of transhumant herds in the Sudano-Sahelian/Sudano-Guinean zones of Mali in the past 30 years, there has been limited research on the practice of transhumance in these zones, compared to several studies in the Sahelian zone. In this paper, we present how various actors in two districts in the Sudano-Sahelian/Sudano-Guinea zones of Mali perceived the effect of transhumant practices on natural resource management. Results from the study showed that more than $75 \%$ of all categories of respondents in both study sites perceived a decline in availability of forage resources and water as a result of the increased number of transhumant herders in their communities. Furthermore, a greater proportion of farmers and settled pastoralists in both study sites responded that there has been a decline in species richness of the vegetation. In contrast, more than 50\% of transhumant herders did not see any change in species richness of natural vegetation due to their presence. They argued that the observed decline in species richness of the vegetation is due to climate change. Education level, location and socio-professional categories tended to be the key factors influencing respondent's perception on the impact of transhumant practices on natural resource management. As the perceived impact of transhumant practices depends on socio-professional groups, it is necessary to engage all the actors on how to effectively manage the presence of transhumant herders, in order to promote sustainable use of natural resources in southern Mali. Besides, more research is needed to assess the validity of the reported perceptions in this study.
\end{abstract}

Keywords: Transhumance, Perception, Natural resources, Farmer-herder relation, Mali

\section{Introduction}

Transhumance, defined as livestock production system characterized by seasonal and cyclical mobility of animals between complementary ecological areas (Niamir-Fuller 1999; SWAC/OECD 2007), is one of the dominant livestock production systems in the West African Sahel. These movements of livestock are adapted to areas where natural resource availability is highly variable in time and space (Niamir-Fuller 1999). There is a general consensus that transhumance is essential to maintaining ecological resilience of dryland ecosystems

\footnotetext{
* Correspondence: a.ayantunde@cgiar.org

IInternational Livestock Research Institute (ILRI), B.P. 1496, Ouagadougou,

Burkina Faso

Full list of author information is available at the end of the article
}

and ensuring livestock productivity (Niamir-Fuller 1999; Ayantunde et al. 2014). However, despite the acknowledged advantages of mobility, transhumant practices in Sudano-Sahelian and Sudano-Guinean zones are facing increasing challenge in the context of demographic pressure, leading to the encroachment of cultivated fields into grazing areas and livestock corridors which constrains the mobility of animals (Ayantunde et al. 2014).

The general trend of transhumance practices in West Africa in the recent past, as reported by Bassett and Turner (2007) and Umutoni et al. (2016b), has been towards increasing livestock movement into SudanoSahelian and Sudano-Guinean zones. These increased movements have occurred for different reasons as observed by Bassett (1986), Thebaud and Batterbury (2001) 
and Bassett and Turner (2007). For example, the severe droughts of the early 1970s and mid-1980s triggered the southward expansion of livestock movements characterized by regular north-south pattern during the dry season to access green vegetation when it is unavailable in the north (Tonah 2003; Bassett and Turner 2007; Turner et al. 2014). The southward movement of transhumant herds has been partly facilitated by better veterinary services at the destinations and national/regional policies that support transhumance such as the Pastoral Charter in Mali (Bassett 1986; République du Mali 2001; Tonah 2003) and the 1998 agreement among the 15 nations of the Economic Community of West African States (ECOWAS) (SWAC-OECD/ECOWAS 2008) on livestock mobility in the region. Natural resources are impacted directly or indirectly by this trend of increasing presence of transhumant herds in the Sudano-Sahelian and Sudano-Guinean zones. According to Ayantunde et al. (2014) and Umutoni et al. (2016b), the increased presence of transhumant herders in these zones has resulted in increasing competition over natural resources and may lead to natural resource degradation. Ayantunde et al. (2014) stated that stakeholders, mainly Indigenous farmers, tended to portray the transhumant practices as generally bad for community-based natural resource management (NRM). In some Sahelian countries, local farmers have been reported to complain that the transhumant herders overexploit the scarce natural resources, which may consequently contribute to environmental degradation (Folly 1997; Tonah 2003). The most significant effects reported include increased incidence of uncontrolled bush fire and abusive cutting of trees by the pastoralists as well as overgrazing (Bernardet 1986; Folly 1997; Green and Tchinlé 2004; Ayantunde et al. 2014; Kiema et al. 2014). Furthermore, according to Ayantunde et al. (2014), uncontrolled bush fire is a major threat to sustainable natural resource management, which may have direct or indirect effects on the ecosystem of the endemic ruminant livestock in the West African sub-humid zone. Another reported effect associated with the herders' presence is the unauthorized grazing of crop residues by the transhumant herds, which may lead to conflict between farmers and herders (Ayantunde et al. 2014). In this sense, some studies (Brockhaus et al. 2003; Moritz 2010; Umutoni et al. 2016b) have reported an increase in conflicts between farmers and herders in the West African Sahel. Authors who have addressed the question of competition over natural resources and the associated conflict between farmers and herders in West Africa include Blench (1994), Thebaud and Batterbury (2001), Richards (2001), Bassett and Crummey (2003), Turner (2004) and Moritz (2006). Some of these studies illustrate how increased competition for specific key resources has risen over the past 30 years. Some other authors such as Bächler (1999) and Homer-Dixon (1999) see this increased competition over natural resources as an important factor leading to environmental degradation in areas where livestock mobility has increased. Despite this trend, not many studies have been carried out to assess the impact of transhumance on natural resource management as perceived by the main actors (farmers and herders) in the Sudano-Sahelian and Sudano-Guinean zones of Mali. Assessing the impact of transhumance on natural resources in these agro-ecological zones of Mali is necessary to better understand the current situation and to identify strategies to address the challenges and to strengthen local natural resource institutions taking into consideration all the interest groups.

This study focuses on the perceived effects of transhumant practices on natural resource management at host communities by various actors (transhumant pastoralists, settled pastoralists and farmers). In this study on perceptions, we try to address the question as to what extent natural resources and social relations between transhumant herders and host communities are affected by the increased movement of livestock into the southern zone of Mali. Thus, this qualitative research attempts to address the following questions: (1) What are perceptions of transhumance and their impact on natural resources? (2) What are perceptions of relations between transhumant pastoralists and their hosts? (3) What are the factors influencing individuals' perceptions of impact of transhumant practices on NRM? The main objective of this study was to document the perceptions of key natural resource users of the impact of transhumant practices on NRM in southern Mali. Understanding perceptions of individuals is critical and can be used as a basis to develop more effective strategies to better manage natural resources. Understand perceptions can also strengthen relations between farmers and herders, to enhance the sustainability of transhumant practices and livelihoods of people who depend on transhumance.

\section{Theoretical perspectives underpinning transhumance in the Sudano-Sahelian/Sudano-Guinean zones}

Transhumance is regarded as an important livestock production system in Mali as it involves 70 to $80 \%$ of national herds (Ham et al. 2012). Transhumance can be described as animal husbandry involving moving animals in ways that best exploit natural resources (SWAC/ OECD 2007; Adriansen 2008; Moritz et al. 2009). This system is based on opportunistic and seasonal exploitation of natural resources (Scoones 1995; Marty et al. 2006). Transhumance livestock systems have been recognized as an efficient and adaptive use of dryland vegetation and water resources as explained by the mobility 
paradigm underpinning transhumance in West Africa (Moritz 2008; Ayantunde et al. 2014). Niamir-Fuller (1999) and Martin et al. (2014) observed that livestock mobility is necessary to improve livestock nutrition, move livestock away from cropped fields, better calibrate livestock grazing pressure to forage availability and to enhance system-level resilience to climate change and variability. The common pattern of transhumance is moving the herds to access better quality pastures (Adriansen and Nielsen 2002). Thus, for the selection of grazing itineraries, transhumant herders look for information on the availability and quality of pastures and the availability of water and crop residues. Turner et al. (2016) viewed transhumant herders' movements through the lens of a network of interconnected resources providing alternative options for travel, water and forage as herds move along a north to south trajectory, shaped by climate, cropping pressure and social institutions.

Generally, transhumance in West Africa is strongly associated with the presence of pasture and water, considered as primary pull factors towards an area. The pull and push factors or stimuli-response (Asse et al. 2010) are based on human migration dynamics that positive socio-economic, environmental and socio-political factors 'pull' transhumant herders towards a particular area and in parallel manner, negative factors such as feed and water scarcity, civil strife, 'push' transhumant herders out of a particular area. Studies by Bassett and Turner (2007) and Ayantunde et al. (2014) have shown that livestock movements in West Africa are oriented along a north to south axis to seasonally take advantage of different rangeland ecologies. Bassett (1988) observed that poor quality of pasture and the progressive drying up of watering places during the dry season led to increased movement southward by the transhumant herders to where good pastures and adequate water were still available. Transhumant patterns and regularity are quite predictable due to seasonal and spatial variations of resources (Bassett 1986).

Despite the long history of transhumant herders' seasonal movements into the Sudanian zones of West Africa to take advantage of pastures and water, there are conflicting national policies on transhumance in the region; these policies are based on the modernization paradigm that sees mobile pastoralism as backward (Asse et al. 2010). Hence, transhumance is considered to be socio-ecologically inappropriate in the Sudanian zones. From the lens of the modernization paradigm, there is no room or future for mobile pastoralism or transhumance in the Sudanian zones. However, the recent realities in terms of rapid population growth, significant increase in livestock owned by the indigenous population in the Sudanian zones and the settlement of many pastoralists in the areas, imply that livestock can no longer be considered as secondary in these zones.

Cooperation/interaction between transhumant herders and host communities has changed over the past three decades. As the supply of natural resources declines and/or the demand increases, competition over these resources becomes increasingly intense; this tends to affect the day-to-day relations between the transhumant herders and their host communities. As explained by Tonah (2003), the relationships between transhumant herders and farmers' groups appeared to be generally harmonious and mutually beneficial in the past. As an example of this past good relationship, the transhumant herders developed economic exchanges with farming communities and utilized their superior herding skills to the benefit of both groups. Evidence from the past studies suggests that the demise of host-client relations (economic interdependency of herders and farmers) contributed to increasing conflict between the two groups (Blench 1994).

In many countries in the Sahel, the growing distrust between the two groups resulted from competition over declining natural resources (Tonah 2003; Moritz 2006). Particularly, there have been reported cases of conflict arising from the destruction of crops in the host communities by the transhumant herds (Tonah 2003; Moritz 2006), which has contributed to deteriorating relationships between transhumant herders and local farmers. However, it has been observed that the stress of crop damage alone is not a sufficient condition for tension between the host communities and the transhumant herders (Bassett 1988; Moritz 2006). On the linkage between natural resource scarcity and environmental degradation, Turner (2004) observed that the juxtaposition of resource scarcity and competition over exploitation in African drylands makes them a popular backdrop to causal statements linking scarcity to overexploitation and degradation, although this perspective has been criticized by political ecologists like Peluso and Watts (2001). These authors reject the automatic, simplistic linkage between resource scarcity and conflict. According to Turner (2004), farmer-herder conflict has often been linked to environmental degradation by the Sahelian people, particularly the host farming communities in the Sudano-Guinean zone. For example, farmers routinely present pastoralists as marauding groups overgrazing pasture and cutting down trees, which leads to natural resource degradation. However, the Fulbe pastoralists are united in their rejection of being responsible for environmental degradation in the host communities (Tonah 2003). Looking closely at the root causes of resource degradation, institutional factors are much to blame as degradation is seen as a result of failure in managing common resources (Marty 1993; Goldman 1998; Turner 1999). 


\section{Study area}

This study was carried out in two districts, Bougouni and Koutiala, in the southern part of Mali (Figure 1). Bougouni is located at $11^{\circ} 16^{\prime} 1^{\prime \prime} \mathrm{N}$ and $7^{\circ} 20^{\prime} 51^{\prime \prime} \mathrm{W}$, and Koutiala is located at $12^{\circ} 38^{\prime} \mathrm{N}$ and $5^{\circ} 66^{\prime} \mathrm{W}$. The study sites are characterized by a Sudanian climate with a mono-modal rainfall pattern of about four to five months. Annual precipitation varies between 750 to $1100 \mathrm{~mm}$ and 900 to $1200 \mathrm{~mm}$ for Koutiala and Bougouni, respectively. The two districts and the three study communities in each district were among the intervention communities of Africa RISING project in Mali.

\section{Background}

The project intervention communities are in the 'Zones of Influence' of United States Agency for International Development (USAID) Program in Mali, the donor for the Africa RISING project under the US government's Feed the Future Initiative. The overall goal of the project is to create opportunities for smallholder farm households to move out of hunger and poverty through sustainably intensified farming systems that improve food, nutrition and income security, particularly for women and children, and conserve or enhance the natural resource base. The Africa RISING project focuses on mixed crop-livestock systems. Transhumance is one of the issues being addressed as it is very important in the project intervention communities in Mali which are either transit or destination points for the transhumant herders from the Sahelian zone. Hence, one of the hypothesis of Africa RISING project in Mali is: 'Building social cohesion and local institutions for improved community land, water and grazing management will lead to reduced land degradation, forest clearing, and conflict over natural resource use'. In addressing transhumance issues, the project has worked on elaboration and formalization of the local natural resource institutions within the context of decentralization reform in the

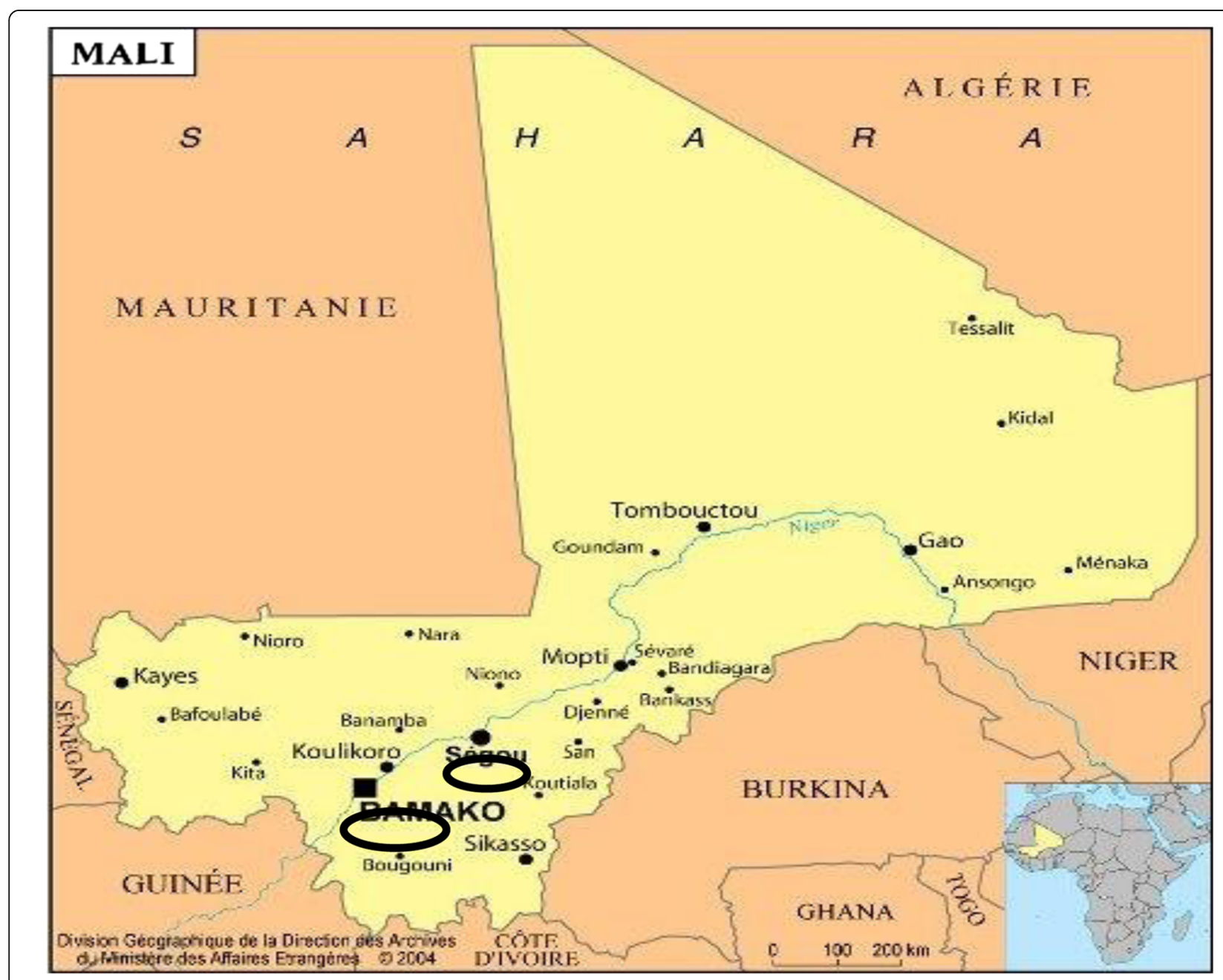

Figure 1 Map of Mali showing Bougouni and Koutiala districts, southern Mali (study location) 
West African Sahel, and participatory management of conflict between the host communities and the transhumant herders.

The project study sites in Bougouni and Koutiala districts in southern Mali were selected based on agroecological potential and opportunities for intensification of the farming systems, and market access. The two study sites provide a good contrast in terms of market access and status of natural resources, which are essential to intensification of the farming systems in the region. Besides, the two districts are important for transhumance either as the transit or destination point for the transhumant herders from the Sahelian zone (Gao, Tombouctou, Ségou, Mopti) and the SudanoSahelian zone of Mali (Koulikoro, Kaye). These study sites are in the region with the highest agricultural production in Mali and where pasture resources are available especially during the dry season when forage resources elsewhere have been depleted.

Generally, Koutiala is a transit zone for transhumant herders from the Sahel while Bougouni is a destination point. This is explained by the length of stay of transhumant herders in these zones. The duration of transhumant herders in the area and their itinerary is largely dictated by the availability and quality of water and pasture. From a study conducted by Umutoni et al. (2016b), it was reported that the transhumants' length of stay has sharply decreased in Koutiala due to the scarcity of grazing resources and lack of watering points. In contrast to Koutiala, the transhumants' length of stay has increased in Bougouni, where the transhumant herders can stay up to three months, due to the availability of fodder and water resources. In the study areas, farmers and settled pastoralists live in harmony as one single group. Besides, most of the settled pastoralists have been living in the study sites for more than 30 years, and they do have access to land for cropping.

The study areas' population is composed of diverse ethnic groups who historically have been identified as farmers or pastoralists. The main ethnic groups in Bougouni are the Bambara, the Peulh, the Sarakolé, the Malinke, the Dogon and the Bozo, of which the Bambara and Peulh are numerically dominant. The Bambara are an indigenous people while other ethnic groups, especially the Peulh, are immigrants who settled in southern Mali. Koutiala is a cosmopolitan town with dominance of the Minianka ethnic group, constituting more than $50 \%$ of the population, while the Bambara and the Sarakole ethnic groups constitute 20 and $10 \%$, respectively. The Minianka and the Bambara are considered as indigenous people in Koutiala. In both sites, the livelihoods of farmers are based on cereal (maize, millet and sorghum) production for household consumption and cotton, the main cash crop in southern Mali. In addition to crop farming, the people in both study sites are engaged in animal husbandry, keeping cattle, sheep, goats and poultry. Agricultural production in the study sites is largely rain-fed.

\section{Methods \\ Data collection}

Data were collected during the period when transhumant herders were present in the study sites (February to April 2014) to ensure inclusion of transhumant herders' perspectives. Focus group discussions as well as individual interviews were employed for data collection on transhumant practices in the study sites. The purpose of combining individual interviews and focus group discussions was to enhance data richness. This combination helped in achieving more understanding of stakeholders' perceptions. According to Gill et al. (2008), qualitative methods such as focus group discussions and individual interviews are believed to provide a 'deeper' understanding of social phenomena than would be obtained from purely quantitative methods.

\section{Focus group discussions}

The focus group discussions were conducted with at least 10 farmers and settled pastoralists in each study community (Namposséla, Sirakelé and Zanzoni in Koutiala district; Sibilira, Diéba and Yorobougoula in Bougouni district) to document their perceptions about the impact of transhumant practices on natural resources in their communities. The participants at the focus group discussion were mainly opinion leaders in each community, selected based on the recommendation of the village chief and the mayor of the "commune rurale'. The participants have stayed in the community for at least 30 years, so are able to speak of the changes in natural resource base that might have occurred over the period. Only the persons resident in the study communities (farmers and settled pastoralists) were involved in the focus group discussions; therefore, transhumant pastoralists did not participate in the focus group discussions. Willingness to participate and ability to share their knowledge were other criteria that guided the selection of participants. The group discussions focused on assessing how transhumant practices affect natural resource management in the host communities and on how respondents perceived the cooperation/interaction between transhumant herders and their host communities.

\section{Individual interviews}

A semi-structured interview of three social groups concerned with transhumance in the study sites was carried out to collect information on transhumant practices and the perceived effects on natural resources in the areas. The target social groups for the study were the 
transhumant herders, settled pastoralists and farmers. Individual interviews were conducted with 177 interviewees randomly selected from the three target social groups (Table 1). It should be pointed out that more farmers were interviewed in the study sites (Bougouni and Koutiala) because of their high number compared to the other groups. The interviewees were randomly selected from the list of household heads for each community, except for the transhumant herders where all who were encountered during the surveys were interviewed due to their small number. Only farmers and settled pastoralists who have lived in the study communities for at least 30 years were selected for the interview. About $10 \%$ of the farmers and settled pastoralists were sampled in each site, as recommended by Lapan et al. (2012) for social science survey.

Information gathered during these interviews included day-to-day relations and interactions between transhumant herders and host communities, and the perceived impact of transhumant practices on NRM over the past 30 years.

To document the perceived magnitude (extent) of the impact of transhumant practices on NRM, the respondents were asked to rate their perceived possible impact of transhumance on a scale of 0 (no impact) to 4 (very high impact) in response to a series of statements.

Very high impact: the impact of transhumance on natural resource management is perceived to be very high and is easily observable.

High impact: transhumance is perceived to have high impact on natural resource management.

Moderate impact: transhumance is perceived to have a moderate impact on natural resource management.

Low impact: transhumant practices has little impact on natural resource management.

No impact: transhumance practices has no impact on natural resource management.

Besides, we also collected information on the quality of relations between transhumant herders and farmers

Table 1 Category of respondents involved in individual interview

\begin{tabular}{lllll}
\hline \multirow{2}{*}{ Sites } & & \multicolumn{3}{l}{ Number of respondent } \\
\cline { 3 - 5 } & Social group & 37 & Momen & Total \\
\hline Bougouni & Farmers & 13 & 4 & 45 \\
& Settled pastoralists & 24 & 0 & 17 \\
& Transhumant herders & 53 & 12 & 24 \\
\multirow{3}{*}{ Koutiala } & Farmers & 16 & 2 & 65 \\
& Settled pastoralists & 8 & 0 & 8 \\
\hline
\end{tabular}

by asking people if the quality of the current relation between both groups was good, average, indifferent or bad.

The questions posed to the interviewees were openended. Each interviewee was first asked about the trend of different elements of natural resource management (e.g. incidence of uncontrolled bush fire, abusive tree cutting, primary productivity of vegetation, species richness, availability of water) in the community over the past 30 years. Each interviewee was then asked the causes of the perceived change in trend and the level of change. The farmers and settled pastoralists were never asked directly whether transhumance herders were the cause of any perceived negative trend.

We need to emphasize that this is a study on perceptions and the obvious challenge is collecting credible data based on perceptions of the respondents. To ensure validity of the perceptions revealed by the farmers, settled pastoralists and transhumant pastoralists, the survey was led by a local Malian NGO (called AMEDD) which has a good relationship with the study communities. The NGO has been intervening in the study communities for at least 15 years on different issues including child nutrition, natural resource management, farmers' field school and elaboration of local natural resource institutions and conflict management between the farmers and herders. Besides, conducting focus group discussions and individual interviews is recommended for data triangulation, to ensure reliability of the information provided by the respondents. Based on the abovementioned points, we believe that the perceptions revealed by the farmers, settled pastoralists and the transhumant pastoralists are genuine. Besides, the responses provided by the respondents are supported by relevant publications on the subject.

\section{Statistical analysis}

Data were analyzed with SPSS (version 20). Descriptive statistics were used to analyze interviewees' perception on transhumant practices and the effects on natural resource management. Chi-square was used to determine whether there is a significant difference between the two sites in the respondents' perception on the impact of transhumant practices on natural resource management. The recorded scores on the magnitude of impact of transhumant practices on NRM were used to calculate the average for each social group.

This study employed an 'ordered probit' regression model to analyze factors influencing respondent's perception of impact of transhumant practices on NRM in the study sites. This model estimates the effect of explanatory variables explained in Table 2 [location (transit zone, destination zone), age, gender, education level and socio-professional category] on dependent variables 
Table 2 Description of the independent variables used in the regression analysis

\begin{tabular}{ll}
\hline $\begin{array}{l}\text { Independent } \\
\text { variable }\end{array}$ & Description \\
\hline Age & Age of respondents (year) \\
Location & $\begin{array}{l}1 \text { if location is Bougouni (transhumant herders' } \\
\text { destination zone), } 2 \text { if location is Koutiala } \\
\text { (transhumant herders' transit zone) }\end{array}$ \\
Sex & 0 if sex is female, 1 if sex is male \\
Education level & $\begin{array}{l}0 \text { if no education, } 1 \text { if level of education is a formal } \\
\text { education (primary, secondary school, university), }\end{array}$ \\
& $\begin{array}{l}2 \text { if the education is an informal education } \\
\text { (koranic education or adult education) }\end{array}$ \\
Socio-professional & $\begin{array}{l}1 \text { if the respondent is a farmer, } 2 \text { if the respondent } \\
\text { is a settled pastoralist, } 3 \text { if the respondent is a } \\
\text { groups }\end{array}$ \\
\hline
\end{tabular}

The high value for each variable has been taken as reference variable

(incidence of uncontrolled bush fire, availability of pastoral resources, abusive cutting of trees, unauthorized grazing of crop residues, incidence of conflict, spread of invasive species, soil fertility improvement, loss of biodiversity (flora and fauna), annual production of vegetation) involving multiple choices with ordered response categories (decrease, no change and increase). The advantage of ordered probit model lies in the fact that it takes into consideration the difference among responses (decrease, no change, and increase). The model also assumes that the two respondents who give the same response do not have exactly the same attitude.

\section{Results}

Respondent's perceptions of effect of transhumant practices on natural resource management over the past $\mathbf{3 0}$ years

Our results showed that the majority of respondents perceive potential effects of transhumant practices on NRM. Their perceptions of the impact on different NRM variables are presented in Table 3. In Bougouni district, $56 \%$ of interviewed farmers as well as $71 \%$ of settled pastoralists linked the increase in incidence of uncontrolled bush fire to the presence of transhumant herders in their communities. However, the transhumant herders did not agree with that as $71 \%$ of them reported that there was no link between transhumant practices and increase in the incidence of uncontrolled bush fire. In Koutiala, a greater proportion of settled pastoralists (67\%) reported a negative correlation between incidence of uncontrolled bush fire and the presence of transhumant herders.

More than $75 \%$ of all categories of respondents in both study sites perceived a decrease in availability of forage resources and water over the past 30 years, partly due to the increasing number of transhumant herds in the communities. A greater proportion of farmers and settled pastoralists in both study sites perceived a decline in species richness of vegetation. However, more than $50 \%$ of transhumant herders responded that they did not see any change in species richness of vegetation due to their presence. They argued that the observed decline is due to climate change.

Nearly all farmers and settled pastoralists interviewed in Bougouni were of the opinion that abusive cutting of trees has increased in their communities in the past 30 years due to the presence of transhumant herders. Only $33 \%$ of transhumant herders agreed while $42 \%$ reported that the abusive cutting of trees was not due to their presence. In addition, the majority of farmers, settled pastoralists and transhumant herders in Bougouni observed an increase in unauthorized grazing of crop residues. In Koutiala, by contrast, a decline in unauthorized grazing of crop residues was reported due to the enforcement of rules regulating access to crop residues after crop harvest.

The distribution of the respondents' perception regarding incidence of conflict over natural resources revealed that $83 \%, 88 \%$ and $63 \%$ of farmers, settled pastoralists and transhumant herders, respectively, observed an increasing trend over the last 30 years due to transhumant practices in Bougouni, while in Koutiala district, the higher proportion of the respondents did not associate incidence of conflict with the presence of transhumant herders.

Another possible effect of transhumant practices on NRM reported especially in Bougouni was the spread of invasive species where about $95 \%$ of farmers and settled pastoralists perceived an increase in invasive species. The dispersal of invasive species' seeds was often through animals' skin or through faeces, according to the interviewees. The respondents in the focus group discussions reported that the invasive species have a negative impact on cultivated land, grazing area and natural pastures, as the invasive species constituted weeds and tend to replace good forage species. They also reported that invasive species sometimes result in the poisoning of livestock when consumed, due to their toxic content. The invasive species can also reduce the habitats of native and endangered species through the reduction of plant cover. Invasive species were also reported by the respondents to compete with crops for soil nutrients and water. In line with this, a decrease in soil fertility was mentioned in Bougouni by $49 \%, 82 \%$ and $42 \%$ of farmers, settled pastoralists and transhumant herders, respectively. An increase in loss of biodiversity (fauna and flora) was reported by $75 \%$ and $82 \%$ of farmers and settled pastoralists, respectively, in Bougouni while in Koutiala, almost all respondents did not see any association between loss of biodiversity (fauna and flora) and transhumant practices. 
Table 3 Respondents' perceptions of impact of transhumant practices on NRM in southern Mali

\begin{tabular}{|c|c|c|c|c|c|c|}
\hline \multirow[t]{2}{*}{ Parameters } & \multicolumn{3}{|l|}{ Bougouni } & \multicolumn{3}{|l|}{ Koutiala } \\
\hline & Farmers (\%) & Settled pastoralists (\%) & Transhumant herders (\%) & Farmers (\%) & Settled pastoralists (\%) & Transhumant herders (\%) \\
\hline \multicolumn{7}{|c|}{ Incidence of uncontrolled bush fire } \\
\hline Increase & 56 & 71 & 21 & 9 & 0 & 0 \\
\hline No change & 37 & 23 & 71 & 59 & 33 & 88 \\
\hline Decrease & 7 & 6 & 8 & 32 & 67 & 12 \\
\hline \multicolumn{7}{|c|}{ Availability of forage resources } \\
\hline Increase & 7 & 0 & 4 & 1 & 6 & 0 \\
\hline No change & 0 & 18 & 4 & 20 & 5 & 12 \\
\hline Decrease & 93 & 82 & 92 & 79 & 89 & 88 \\
\hline \multicolumn{7}{|c|}{ Abusive cutting of trees } \\
\hline Increase & 94 & 100 & 33 & 68 & 44 & 0 \\
\hline No change & 2 & 0 & 42 & 32 & 50 & 100 \\
\hline Decrease & 4 & 0 & 25 & 0 & 6 & 0 \\
\hline \multicolumn{7}{|c|}{ Unauthorized grazing of crop residues } \\
\hline Increase & 58 & 71 & 46 & 26 & 28 & 0 \\
\hline No change & 2 & 0 & 33 & 22 & 11 & 63 \\
\hline Decrease & 40 & 29 & 21 & 52 & 61 & 37 \\
\hline \multicolumn{7}{|c|}{ Incidence of conflict over NR } \\
\hline Increase & 83 & 88 & 63 & 20 & 28 & 38 \\
\hline No change & 13 & 8 & 25 & 80 & 72 & 62 \\
\hline Decrease & 4 & 4 & 12 & 0 & 0 & 0 \\
\hline \multicolumn{7}{|c|}{ Species richness of the vegetation } \\
\hline Increase & 0 & 0 & 13 & 1 & 0 & 0 \\
\hline No change & 0 & 0 & 58 & 34 & 22 & 75 \\
\hline Decrease & 100 & 100 & 29 & 65 & 78 & 25 \\
\hline \multicolumn{7}{|c|}{ Spread of invasive species } \\
\hline Increase & 96 & 94 & 33 & 9 & 6 & 0 \\
\hline No change & 4 & 0 & 59 & 63 & 44 & 100 \\
\hline Decrease & 0 & 6 & 8 & 28 & 50 & 0 \\
\hline \multicolumn{7}{|c|}{ Soil fertility improvement } \\
\hline Increase & 47 & 12 & 21 & 42 & 56 & 63 \\
\hline No change & 4 & 6 & 37 & 33 & 33 & 37 \\
\hline Decrease & 49 & 82 & 42 & 25 & 11 & 0 \\
\hline \multicolumn{7}{|c|}{ Loss of biodiversity (flora and fauna) } \\
\hline Increase & 75 & 82 & 25 & 23 & 22 & 0 \\
\hline No change & 9 & 0 & 54 & 74 & 78 & 87 \\
\hline Decrease & 16 & 18 & 21 & 3 & 0 & 13 \\
\hline \multicolumn{7}{|c|}{ Annual production of vegetation } \\
\hline Increase & 0 & 6 & 8 & 0 & 5 & 0 \\
\hline Decrease & 96 & 94 & 46 & 68 & 56 & 0 \\
\hline No change & 4 & 0 & 46 & 32 & 39 & 100 \\
\hline
\end{tabular}

In Bougouni district, the percentage of transhumant herders reporting a decline in annual production of vegetation (46\%) was equal to those reporting no change. However, a high proportion of farmers and settled pastoralists in both study sites associated a decline of annual production of vegetation to the increased presence of transhumant herders. 
Table 4 Perceived magnitude of impact of transhumant practices on NRM in southern Mali

\begin{tabular}{|c|c|c|c|c|c|c|}
\hline \multirow[t]{2}{*}{ Parameters } & \multicolumn{3}{|l|}{ Bougouni } & \multicolumn{3}{|l|}{ Koutiala } \\
\hline & Farmers & $\begin{array}{l}\text { Settled } \\
\text { pastoralists }\end{array}$ & $\begin{array}{l}\text { Transhumant } \\
\text { herders }\end{array}$ & Farmers & $\begin{array}{l}\text { Settled } \\
\text { pastoralists }\end{array}$ & $\begin{array}{l}\text { Transhumant } \\
\text { herders }\end{array}$ \\
\hline Incidence of uncontrolled bush fire & Low/+ & Moderate/+ & Low/+ & Low/- & Moderate/- & None \\
\hline Availability of pastoral resources & High/- & High/- & Moderate/- & Moderate/- & Moderate/- & Low/- \\
\hline Abusive cutting of trees & $\mathrm{High} /+$ & Very high/+ & Very low/+ & Low/+ & Low/+ & None \\
\hline Unauthorized grazing of crop residues & Low/+ & Low/+ & Low/+ & Low/- & Low/- & Low/- \\
\hline Incidence of conflict & Moderate/+ & High/+ & Low/+ & Very low/+ & Low/+ & Low/+ \\
\hline Species richness of the vegetation & Very high/- & High/- & Moderate/- & Low/- & Low/- & Low/- \\
\hline Spread of invasive species & $\mathrm{High} /+$ & Moderate/+ & Low/+ & Low/- & Low/- & None \\
\hline Soil fertility improvement & Very low/+ & Moderate/- & Low/- & Very low/+ & Low/+ & Moderate/+ \\
\hline Loss of biodiversity (flora and fauna) & Moderate/+ & Moderate/+ & Very low/- & Very low/+ & Low/+ & Very low/- \\
\hline Annual production of vegetation & Moderate/- & Moderate/- & Low/- & Low/- & Low/- & None \\
\hline
\end{tabular}

The signs " - " and " + " illustrate respectively a decrease and an increase for a given variable

Table 4 presents in general the magnitude of the perceived impact of transhumant practices on NRM. The increase in abusive cutting of trees, incidence of conflict over natural resources and spread of invasive species were perceived as high in Bougouni by farmers and settled pastoralists. However, the transhumant herders perceived this increase as generally low. In Koutiala, both farmers and settled pastoralists reported a slight increase in abusive cutting of trees. The magnitude of the decline in availability of forage and water resources was reported to be high and moderate in Bougouni and Koutiala districts, respectively, by both farmers and settled pastoralists. The transhumant herders reported a moderate and a slight decline in the availability of feed resources as a result of transhumant practices in Bougouni and Koutiala, respectively. Generally, the increased loss of biodiversity reported was seen as low by all the three social groups in both study sites. There was a positive perception regarding soil fertility and transhumant practices in Koutiala.

\section{Determinants of perceived effects of transhumant practices on natural resource management}

The results of ordered probit analysis on the respondents' perception of the impact of transhumant practices on NRM are presented in Table 5. Except for the variable 'availability of forage resources and water', the likelihood ratio statistics for other variables as indicated by $\chi^{2}$ are significant at $1 \%$.

The results indicated that socio-professional categories and location affect respondents' perception. Indeed, the ordered probit analysis revealed that education level, location and socio-professional categories were the main factors significantly influencing a respondent's perceptions of impact of transhumant practices on NRM. Other

Table 5 Results of 'ordered probit' regression model of the respondent's perception of impact of transhumant practices on NRM

\begin{tabular}{|c|c|c|c|c|c|c|c|}
\hline \multirow{2}{*}{$\begin{array}{l}\text { Independent } \\
\text { variable }\end{array}$} & \multicolumn{7}{|c|}{ Perception variables/explanatory variables ( $0=$ Decrease, $1=$ No change; $2=$ Increase) } \\
\hline & $\begin{array}{l}\text { Incidence of } \\
\text { uncontrolled } \\
\text { bush fire }\end{array}$ & $\begin{array}{l}\text { Availability of } \\
\text { forage resources } \\
\text { and water }\end{array}$ & $\begin{array}{l}\text { Abusive cutting } \\
\text { of trees }\end{array}$ & $\begin{array}{l}\text { Species richness } \\
\text { of the vegetation }\end{array}$ & $\begin{array}{l}\text { Spread of } \\
\text { invasive species }\end{array}$ & $\begin{array}{l}\text { Soil fertility } \\
\text { improvement }\end{array}$ & $\begin{array}{l}\text { Incidence of } \\
\text { conflict over NR }\end{array}$ \\
\hline Age & 0.01 & 0.00 & 0.01 & $-0.03^{* * *}$ & -0.002 & -0.01 & -0.004 \\
\hline Bougouni district & $1.55^{* * *}$ & -0.34 & $0.90^{* * *}$ & $-1.1^{* * *}$ & $2.54^{* * *}$ & $-0.71^{* * *}$ & $1.22^{* * *}$ \\
\hline Female & 0.03 & -0.02 & -0.003 & $-0.64^{*}$ & $-0.59^{* *}$ & -0.34 & 0.07 \\
\hline Illiterate & 0.28 & $5.31^{* * *}$ & 0.52 & 0.02 & -0.60 & -0.39 & 0.11 \\
\hline Formal education & $0.71^{*}$ & 5.14 & $0.67^{*}$ & -0.61 & -0.17 & -0.46 & 0.21 \\
\hline Farmers & 0.25 & 0.11 & $1.50^{* * *}$ & $-2.83^{* * *}$ & $1.30^{* * *}$ & 0.19 & 0.39 \\
\hline Settled pastoralists & 0.02 & 0.26 & $1.40^{* * *}$ & $-3.04^{* * *}$ & $0.78^{* *}$ & -0.14 & $0.68^{*}$ \\
\hline$x^{2}(\log$ likelihood $)$ & $64.06^{* * *}$ & 6.98 & $52.82^{* * *}$ & $67.32^{* * *}$ & $127.18^{* * *}$ & $20.12^{* * *}$ & $40.51 * * *$ \\
\hline Pseudo $R^{2}$ & 0.35 & 0.06 & 0.33 & 0.43 & 0.59 & 0.12 & 0.26 \\
\hline
\end{tabular}

*Significant at the $10 \%$ level

** Significant at the $5 \%$ level

***Significant at the $1 \%$ level 
variables such as age and gender had no significant effect on a respondent's perception except for the spread of invasive species and species richness of the vegetation.

Respondents in Bougouni were more likely to observe an increase in incidence of uncontrolled bush fire, abusive cutting of trees, spread of invasive species and incidence of conflict over natural resources than those in Koutiala. And Bougouni's respondents were more likely to report a decrease in the availability of forage resources and water, and soil fertility. The probability of observing a change in species richness of the vegetation tended to increase with age of the respondent. When considering gender, the results showed that male respondents were more likely than female to perceive a significant increase in the spread of invasive species at 5\% level of probability. Furthermore, socio-professional categories appear to influence the likelihood of reporting an increase in abusive cutting of tree, spread of invasive species and a decrease in species richness of the vegetation. For example, farmer and settled pastoralist respondents were more likely to report such increase as a consequence of transhumant practices. In addition, the probability of reporting a change in incidence of uncontrolled bush fire increased with education status.

\section{Perception of respondents on cooperation/interaction between transhumant herders and host communities}

In Bougouni, 53\%, 94\% and 92\% of farmers, settled pastoralists and transhumant herders, respectively, observed that the relations between transhumant herders and host communities were bad as at the time of this study while only $22 \%$ farmers and $6 \%$ settled pastoralists observed that the relation was good (Figure 2). The respondents who reported bad relations between farmers and herders attributed this to conflict between both groups, which are becoming more frequent in the area, especially due to crop damages caused by animals. Some of the farmers stated: 'transhumant herders are our enemy, we don't really want to have any special relation with them, even when they are passing, we have ordered our wives to never interact with them, not even give them water'. In two communities in Bougouni district, respondents in group discussions associated the bad relations with the damages caused in the past by the transhumant herders. 'They have destroyed our forest, our harvest, grazed our crop residues without permission, and sometimes they blocked watering points deliberately', reported by some informants. Some of the farmers interviewed observed that what matters most to the transhumant herders is to gain access to pastures and water for their animals and they do not care about their crops.

Some transhumant herders also shared the same negative views towards the farmers. For example, they said: 'Farmers don't like us; even when we are not responsible, they accuse us for every bad thing occurring in their communities'. 'We and farmers, we are like "dog and cat", stated by one of the transhumant herders interviewed in Bougouni. Both farmers and herders recognized that this was not the case two decades ago. At the focus group discussions, both farmers and settled pastoralists observed that they were in good relationships in the past but with increasing competition for the scarce natural resources, they see each other as competitors nowadays and this has increased the potential for conflict. In Koutiala by contrast, the majority of respondents observed that the relation between transhumant herders and host communities was either good or average. At the focus group discussions, farmers observed that they are in a good relationship with the transhumant herders ,partly due to the short stay of the transhumant herders in the communities as there are no longer enough grazing resources.

\section{Discussion}

The main findings from this study are that farmers, especially in the destination zone of Bougouni district

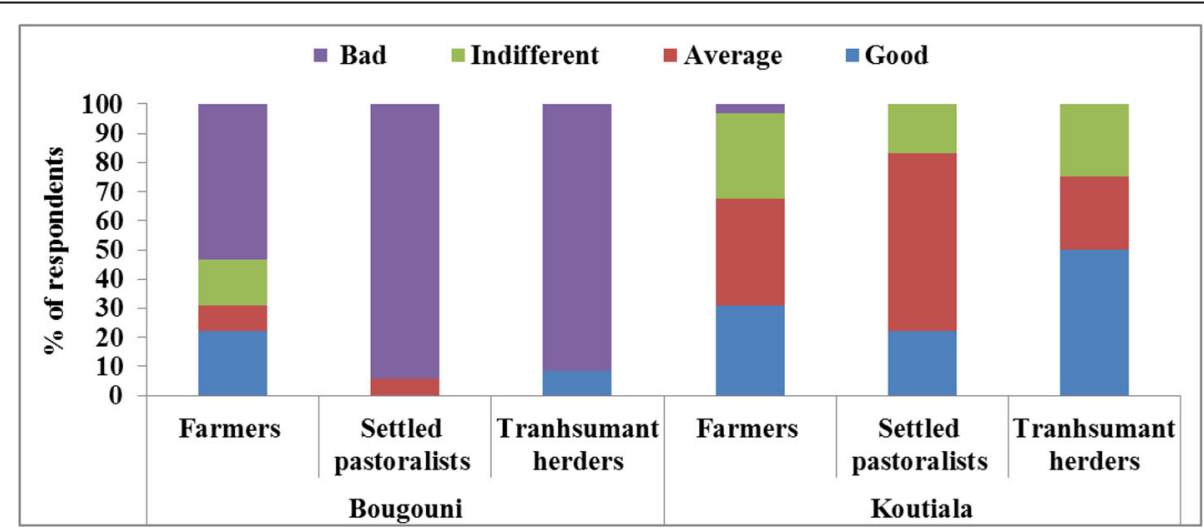

Figure 2 Perception of respondents on social relation between transhumant herders and host communities 
where transhumant herders' presence is high, tended to have a negative impression of transhumant practices on natural resources. Similar negative comments by farmers on transhumant herders have been reported in other studies in the region where local farmers accused transhumant herders of being responsible for natural resource degradation in the host communities (Tonah 2000, 2003). Farmers in this study attributed abusive cutting of trees, decrease in species richness of the vegetation, decline of annual productivity of vegetation and increase in invasive species to transhumant practices. This negative perception could be explained by the dominance of the ethnic groups who are traditionally farmers in the study sites and who recently started to see the transhumant pastoralists as competitors for their natural resources (Turner 2003; Ayantunde et al. 2014). Our results agree with findings from similar studies in West Africa (SWAC/OECD 2007; FAO and CIRAD 2012; Kiema et al. 2014; Ayantunde et al. 2014). FAO and CIRAD (2012) have reported a high incidence of uncontrolled bush fire in Mali, which has contributed to loss of biodiversity and decline in productivity of natural vegetation. Generally, transhumant herders did not share the same opinions as the farmers and settled pastoralists on the effect of transhumant practices on natural resources. The transhumant herders associated the observed change in natural resources in southern Mali to climate change and variability, and demographic pressure. This reaction of transhumant herders was also reported by Tonah (2003), where the transhumant herders, mainly Fulbe herders, were united in their rejection of charges of involvement in environment degradation.

The majority of interviewees in both study sites were of the opinion that transhumant practices contribute to decline in the availability of forage resources and annual production of vegetation. The observed decline in forage resources could be partly attributed to the increased number of livestock arriving in the communities, which resulted in high grazing pressure. Indeed, the reported decline in palatable forage species by farmers and settled pastoralists in the destination zone leading to disappearance of some plant species is corroborated by the findings of Carriere (1996).

The perceived decline in soil fertility due to transhumant practices in Bougouni (transhumant herders' destination zone) may be partly explained by a repetitive tramping of the soil by the grazing animals which may result in erosion and loss of soil nutrients. However, this response by the interviewees in Bougouni should be treated with caution as there is no evidence to suggest that grazing leads to soil degradation from previous studies. On the contrary, other researchers such as Ayantunde et al. (2014) have reported increase in soil fertility due to transhumant practices as was reported in Koutiala, a transit zone of transhumant herders, through the deposition of manure on the fields where they graze.

The perceived increase in unauthorized grazing of crop residues in Bougouni is due to weak enforcement of the rules governing the presence of transhumant herds and the absence of contracts between farmers and herders (Driel 1999). In the past, farmers' and herders' relationship was based on a symbiotic relationship between crop farmers who benefited from traction animals and deposition of manure on their fields, and the transhumant herders who profited from grazing of the crop residues. However, this is no longer the case as crop farmers own livestock, and they use the crop residues to feed their animals. Where there still exists manure contracts between the farmers and transhumant herders, the length of stay of the herders for manure deposition on the crop field has reduced as the crop residue biomass for grazing has reduced significantly due to competition from the farmers' own livestock herd. Thus, the restricted access to grazed residues by transhumant herders has contributed to unauthorized grazing of the farmers' crop fields. This has even contributed to cases of conflict between farmers and herders in southern region of Mali (Umutoni 2016).

Generally, the bad relationship between farmers and herders reported in Bougouni mostly stemmed from crop damages by the transhumant herds, according to the farmers and settled pastoralists. The transhumant herders attributed bad relationships to increasingly restricted access to grazing areas where they used to graze before; this is a reflection of weak local institutions. The cases of crop damage by the transhumant herds have been exacerbated by the proximity of crop field to the transhumant corridors and encroachment of crop fields into the grazing areas. Crop damage by the transhumant herds has been reported as one of the major causes of conflict between farmers and herders (Tonah 2006; Turner et al. 2011; Hellendorff 2012). However, crop damages alone are not sufficient conditions for tension between the farmers and pastoralist herders (Bassett 1988; Moritz 2006). In general, competition over scarce resources has been recognized among the causes of farmers' and herders' conflicts (Bassett and Crummey 2003). Declines in economic exchange between transhumant herders and host communities might have also contributed to weakening relations between both groups, thereby leading to tension and distrust (Blench 1994; Tonah 2003). This observation by the above-mentioned authors is applied to communities in southern Mali where the basis of transhumant herders' interactions with the host communities has been the exchange of milk, or other dairy product against cereals, which is no longer the case. 
In addition, the deterioration of relationships between transhumant herders and host communities is also seen as sign of failure of the local institutions (Blench 1994; Turner 2004). The existing local institutions are sometimes behind in addressing the dynamics of natural resource use in response to demographic pressure and new economic interest. Umutoni et al. (2016a) found that the natural resource institutions in southern Mali are weak, as the majority of them are oral and the participation of the community members in their elaboration was low. Thus, this raises the need for the communities to reinforce local institutions which regulate access to natural resources and use by various actors.

The results of "ordered probit" regression analysis revealed that location, education level and socioprofessional categories are the main factors influencing a respondent's perception of the impact of transhumant practices on NRM in our study sites. The influence of location on respondent's perception might be explained by the differences in extent of the presence of transhumant herds between the two study sites (transit and destination zones). This implies that the presence of high number of transhumant herders in a community coupled with weak local institutions may likely provoke a strong negative perception of the effect on NRM by the host communities.

The fact that aged indigenous respondents are more likely to perceive a decline in species richness of vegetation due to transhumant practices may be explained by respondents' exposure to previous periods of abundant and rich vegetation in the past when there were less animals and a low grazing intensity. The influence of socioprofessional group on respondents' perception on the impact of transhumant practices on NRM might be explained by the fact that members of different socioprofessional groups pursue diverse interests which are sometimes competitive. The results also suggest that men are more likely to perceive increase in invasive species compared to women. This is related to the fact that men are involved in activities such as herding and fodder collection; hence, they may be better placed to observe emergence of new species. The differences in the perceptions of the host communities from the transhumant, particularly with respect to species richness, abusive cutting trees and spread of invasive species, indicate the challenge that will be faced in elaboration and development of local natural resource institutions acceptable to all natural resource users. This may also imply the importance of engaging a third party in the process of institutional development. In the study sites, there are some state agencies and non-governmental organizations actively engaged in facilitation of dialogue between the host communities and the transhumant herders; their aim is to enhance natural resource management and prevent conflict over use of the natural resources.

\section{Conclusions}

The study analyzed the perceptions of farmers, settled pastoralists and transhumant herders on the impact of transhumant practices on natural resource management in southern Mali. The main conclusions from the study are:

- The presence of transhumant herds in southern Mali was perceived to impact differently on natural resources in the destination zone (Bougouni) and in the transit zone (Koutiala) by different social groups.

- Competition for natural resources between transhumant herders and host communities poses significant challenges for community-based natural resource management in southern Mali.

- Farmers and settled pastoralists reported a decline in the availability of forage resources, increase in abusive cutting of trees, conflict over natural resources and loss of biodiversity due to an increase of transhumant practices in southern region of Mali, especially in the destination zone.

- In most cases, transhumant herders differed from the farmers and settled pastoralists in their responses as to the impact of transhumant practices on NRM.

- Location, education level and socio-professional categories are the main factors influencing respondent's perception of impact of transhumant practices on NRM in our study sites.

Given that the perceived impact of transhumant practices depends on socio-professional groups, strengthening natural resource institutions is crucial for creating necessary awareness and to facilitate good natural resource management practices. It is necessary to engage all the actors on how to effectively manage the presence of transhumant herders to promote sustainable use of natural resources in the Sudano-Sahelian and Sudano-Guinean zones of Mali. In addition, attention should be given to the enforcement of policies governing livestock mobility and access to forage and water resources both at local and national levels.

\section{Acknowledgements \\ We are grateful to the respondents in Koutiala and Bougouni districts, south region of Mali, for their kind participation in this study. Furthermore, we thank the Association Malienne d'Eveil pour le Développement Durable (AMEDD) for their strong support in the data collection. This study was conducted under the Feed the Future Africa RISING project in West Africa funded by the United States Agency for International Development (USAID). The authors are solely responsible for the opinions expressed in this paper. \\ Funding \\ This research was funded by United States Agency for International Development (USAID) as a part of Feed the Future Africa RISING project in West Africa. The authors are responsible for the design of the study, for the data collection and analysis and for the decision to submit the article for publication.}

Authors' contributions

CU designed the research protocol; collected, analyzed and interpreted the data and prepared the first draft of the manuscript. AA supervised the research. He led the design of the survey instruments for the study, supervised the data 
collection, made critical review of the draft manuscript and provided input for its improvement. Both authors read and approved the final manuscript.

\section{Ethics approval and consent to participate}

Not applicable

\section{Consent for publication}

Not applicable

\section{Competing interests}

The authors declare that they have no competing interests.

\section{Publisher's Note}

Springer Nature remains neutral with regard to jurisdictional claims in published maps and institutional affiliations.

\section{Author details}

${ }^{1}$ International Livestock Research Institute (ILRI), c/o ICRISAT, B.P. 320, Bamako, Mali. ${ }^{2}$ International Livestock Research Institute (ILRI), B.P. 1496, Ouagadougou, Burkina Faso.

Received: 18 August 2017 Accepted: 24 January 2018

Published online: 09 March 2018

\section{References}

Adriansen, H.K. 2008. Understanding pastoral mobility: The case of Senegalese Fulani. The Geographical Journal 174 (3): 207-222.

Adriansen, H.K., and T.T. Nielsen. 2002. Going where the grass is greener: On the study of pastoral mobility in Ferlo, Senegal. Human Ecology 30 (2): 215-226.

Asse, R., A.A. Ayantunde, A. Fall, and M. Said. 2010. Transhumance and endemic ruminant livestock in sub-humid zone of West Africa-contexts, concepts and challenges: A synthesis report for GEF-AfDB funded project "sustainable management of globally significant endemic ruminant livestock of West Africa" Bamako: International Livestock Research Institute (ILRI).

Ayantunde, A.A., R. Asse, M.Y. Said, and A. Fall. 2014. Transhumant pastoralism, sustainable management of natural resources and endemic ruminant livestock in the sub-humid zone of West Africa. Environment, Development and Sustainability 16: 1097-1117.

Bächler, G. 1999. Violence through environmental discrimination: Causes, Rwanda arena, and conflict model. Dordrecht: Kluwer Academic Publishers.

Bassett, T.J. 1986. Fulani herd movements. The Geographical Review 76 (3): $233-248$

Bassett, TJ. 1988. The political ecology of peasant-herder conflicts in the northern Ivory Coast. Annals of the Association of American Geographers 78 (3): 453-472.

Bassett, T.J., and D. Crummey. 2003. African savannas: Global narratives and local knowledge of environmental change. Oxford: James Currey.

Bassett, T.., and M. Turner. 2007. Sudden shift or migratory drift? FulBe herd movements to the Sudano-Guinean region of West Africa. Human Ecology 35: 33-49.

Behnke, R.H. 1994. Natural resource management in pastoral Africa. Development Policy Review 12: 5-27.

Behnke, R.H., and N. Abel. 1996. Intensification or overstocking: When are there too many animals? World Animal Review 87: 4-9.

Bernardet, P. 1986. Elevage et agriculture dans les savanes du nord. Politique Africaine 24: 29-39.

Blench, R. 1994. The expansion and adaptation of Fulbe pastoralism to subhumid and humid conditions in Nigeria. Cahiers d'études Africaines 34 (133-135): 197-212.

Brockhaus, M., H. Kambiré, T. Pickardt, S. Schliephake, I. Hoffmann, and J. Steinbach. 2003. Conflict management in farmer-herders conflicts in south West Burkina Faso. In Proceedings of the VIlth International Rangelands Congress 26th July-1st August 2003, ed. N. Allsopp, A.R. Palmer, S.J. Milton, K.P. Kirkman, G.I.H. Kerley, C.R. Hurt, and C.J. Brown, 1726-1729. Durban: South Africa

Carriere, M. 1996. Impact des systèmes d'élevage pastoraux sur l'environnement en Afrique et en Asie Tropicale et Sub-tropicale Aride et Sub aride. In Saarbrücken, Allemagne: Scientific Environmental Monitoring Group, Universität des Saarlandes/nstitut für Biogeographie.

Dougill, A., and J. Cox. 1995. Land degradation and grazing in the Kalahari: New analysis and alternative perspectives, Network paper no. 38c. London: Overseas Development Institute.

Driel, A.V. 1999. The end of the herding contract: Decreasing complementary linkage between Fulbe pastoralists and Dendi agriculturalists in northern Benin.
In Pastoralists under pressure? Fulbe societies confronting change in West Africa Brill, ed. V. Azarya, A. Breedveld, M.D. Bruijn, and H.V. Dijk, 191-209. Leiden: Netherlands (Social, economic and political studies of the Middle East and Asia).

FAO, and CIRAD. 2012. Atlas des évolutions des systèmes pastoraux au Sahel 1970 2012. Rapport. Rome: FAO.

Folly, A. 1997. Land use planning to minimize soil erosion- a case study from the upper east region of Ghana, Ph.D. thesis. Denmark: Institute of Geography, University of Copenhagen.

Gill, P., K. Stewart, E. Treasure, and B. Chadwick. 2008. Methods of data collection in qualitative research: Interviews and focus groups. British Dental Journal 204 (6): 291-295.

Goldman, M. 1998. Privatizing nature: Political struggles for the global commons. New Brunswick: Rutgers University Press.

Green, A., and J. Tchinlé. 2004. Evaluation of Mbororo transhumance routes in the Tchabal Mbabo-Dodeo region of Cameroon, Gashaka Gumti-Tchabal Mbabo Transboundary conservation project report. Cameroon: BirdLife International.

Ham, F., N.A. Sow, and T. Métais. 2012. Caractériser les transhumances. In Atlas des évolutions des systèmes pastoraux au Sahel 1970-2012, ed. FAO and CIRAD, 16-17. Rome: FAO.

Hellendorff, B. (2012). Changement climatique et conflits agro-pastoraux au Sahel. Note d'analyse. Bruxelles: Belgique: Groupe de recherche et d'information sur la paix et la sécurité

Homer-Dixon, T.F. 1999. Environment, scarcity, and violence. Princeton: Princeton University Press.

Kiema, A., G.B. Tontibomma, and N. Zampaligre. 2014. Transhumance et gestion des ressources naturelles au Sahel : contraintes et perspectives face aux mutations des systèmes de productions pastorales. VertigO 14 (3). https://doi. org/10.4000/vertigo.15404.

Lapan, S.D., M.T. Quartaroli, and F.J. Riemer. 2012. Qualitative research: An introduction to methods and design. Wiley: Jossey-Bass.

Martin, R., B. Miller, A. Linstadter, and K. Frank. 2014. How much climate change can pastoral livelihoods tolerate? Modelling rangeland use and evaluating risk. Global Environmental Change 24: 183-192.

Marty, A. 1993. La gestion des terroirs et les éleveurs-un outil d'exclusion ou de négociation? Revue Tiers Monde 34 (134): 327-344.

Marty, A., B. Bonnet, and B. Guibert. 2006. La mobilité pastorale et sa viabilité. Entre atouts et défis. Institut de recherches et d'applications des méthodes de développement. Paris: IRAM.

Moritz, M. 2006. Changing contexts and dynamics of farmer-herder conflicts across West Africa. Canadian Journal of African Studies 40 (1): 1-40.

Moritz, M. 2008. Competing paradigms in pastoral development? A perspective from the far north of Cameroon. World Development 36: 2243-2254.

Moritz, M. 2010. Understanding herder-farmer conflicts in West Africa: Outline of a processual approach. Human Organization 69: 138-148.

Moritz, M., B. Kyle, K. Nolan, S. Patrick, M. Shaffer, and G. Thampy. 2009. Too many people and too few livestock in West Africa? An evaluation of Sandford's thesis. Journal of Development Studies 45: 1113-1133.

Niamir-Fuller, M. 1999. Managing mobility in African rangeland. London: Intermediate Technology Publications.

Peluso, N.L., and M. Watts. 2001. Violent environments. Ithaca: Cornell University Press. République du Mali. 2001. Charte pastorale du Mali. Loi No 01-004 du 27 Février, 2001. Bamako: République du Mali.

Richards, P. 2001. Are forest wars in Africa resource conflicts? The case of Sierra Leone. In Violent Environments, ed. N.L. Peluso and M. Watts, 65-82. Ithaca: Cornell University Press.

Scoones, I. 1995. Living with uncertainty: New directions in pastoral development in Africa. Exeter: Intermediate Technology Publications.

SWAC/OECD. 2007. Promoting and supporting change in transhumant pastoralism in the Sahel and West Africa. Paris: SWAC/OECD Policy Note Number 3.

SWAC-OECD/ECOWAS. 2008. Livestock and regional market in the Sahel and West Africa-potentials and challenges. Paris: SWAC-OECD.

Thebaud, B., and S. Batterbury. 2001. Sahel pastoralists: Opportunism, struggle, conflict and negotiation. A case study from eastern Niger. Global Environmental Change 11: 69-78.

Tonah, S. 2000. State policies, local prejudices and cattle rustling along the Ghana-Burkina Faso border. Africa 70 (4): 551-567.

Tonah, S. 2003. Integration or exclusion of Fulbe pastoralists in West Africa: A comparative analysis of interethnic relations, state and local policies in Ghana and Côte d'Ivoire. The Journal of Modern African Studies 41: 91-114.

Tonah, S. 2006. Migration and herder-farmer conflicts in Ghana's Volta Basin. Canadian Journal of African Studies 40: 152-178. 
Turner, M.D. 1999. Conflict, environmental change, and social institutions in Dryland Africa: Limitations of the community resource management approach. Society and Natural Resources 12 (7): 643-657.

Turner, M.D. 2003. Multiple holders of multiple stakes: The multilayered politics of agropastoral resource management in semi-arid Africa. In Proceedings of the VIlth International Rangelands Congress 26th July-1st Auqust 2003, ed. N. Allsopp, A.R. Palmer, S.J. Milton, K.P. Kirkman, G.I.H. Kerley, C.R. Hurt, and C.J. Brown, 1715-1725. Durban: South Africa.

Turner, M.D. 2004. Political ecology and the moral dimensions of "resource conflicts": The case of farmer-herder conflicts in the Sahel. Political Geography 23: 863-889.

Turner, M.D., A.A. Ayantunde, K.P. Patterson, and E.D. Patterson. 2011. Livelihood transitions and the changing nature of farmer-herder conflict in Sahelian West Africa. Journal of Development Studies 47: 183-206.

Turner, M.D., J. McPeak, and A.A. Ayantunde. 2014. The role of livestock mobility in the livelihood strategies of rural peoples in semi-arid West Africa. Human Ecology 42 (2): 231-247.

Turner, M.D., J.G. McPeak, K. Gillin, and E. Kitchell. 2016. Reconciling flexibility and tenure security for pastoral resources: The geography of transhumance networks in eastern Senegal. Human Ecology 44: 199-215.

Umutoni, C. 2016. Analyse des modes de gestion des ressources naturelles dans le cadre didentification des facteurs d'amélioration de la productivité du bétail dans les systèmes mixtes agriculture-élevage en zone soudano-sahélienne du Mali, PhD thesis. Dakar: Université Cheikh Anta Diop.

Umutoni, C., A. Ayantunde, M. Turner, and G.J. Sawadogo. 2016a. Community participation in decentralized management of natural resources in the southern region of Mali. Environment and Natural Resources Research 6 (2): 1-15.

Umutoni, C., A.A. Ayantunde, and G.J. Sawadogo. 2016b. Local knowledge of transhumance practices in the Sudano-Sahelian zone of Mali. Revue d'élevage et de Médecine Vétérinaire des Pays Tropicaux 69 (2): 53-61.

\section{Submit your manuscript to a SpringerOpen ${ }^{\circ}$ journal and benefit from:}

- Convenient online submission

- Rigorous peer review

- Open access: articles freely available online

- High visibility within the field

- Retaining the copyright to your article

Submit your next manuscript at $\gg$ springeropen.com 